\title{
The Impacts of Baseline Retinal Volume on Visual Outcomes in the Treatment of Diabetic Macular Edema
}

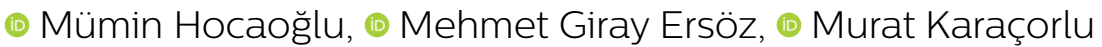

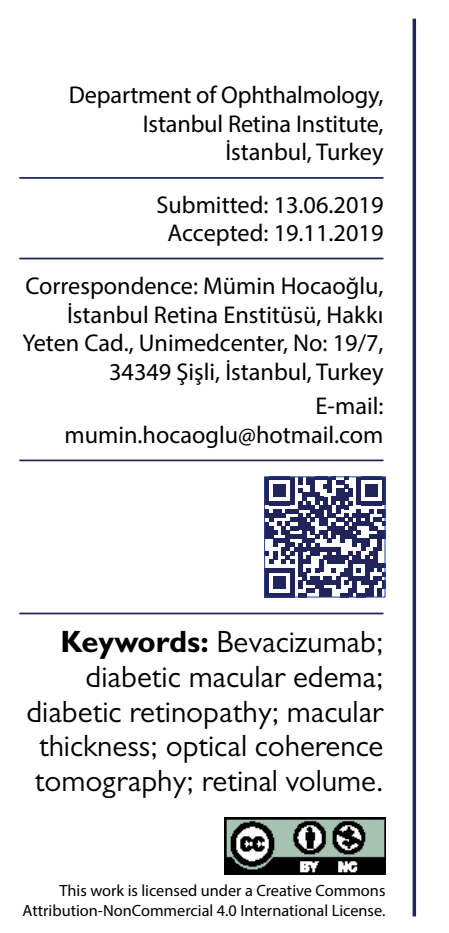

\begin{abstract}
Objective: To assess the effects of initial retinal volume (RV) on visual acuity (VA) after intravitreal bevacizumab treatment for diabetic macular edema (DME).
\end{abstract}

Methods: The data of 28 eyes of 19 patients treated with bevacizumab for clinically significant diabetic macular edema were retrospectively evaluated in this study. The association of visual acuity and letter gain with initial retinal volüme (RV) and central retinal thickness (CRT) after one year of treatment were evaluated.

Results: Baseline VA was 58.9 \pm II.9 letters; CRT was 564.2 \pm I25.I $\mu \mathrm{m}$ and baseline RV was $12.4 \pm 2.3 \mathrm{~mm}^{3}$. At 12 months; VA was $67.4 \pm$ II.6 letter; CRT was $410.2 \pm 124.2 \mu \mathrm{m}$ and $R V$ was $10.6 \pm 2.2 \mathrm{~mm}^{3}(p=0.00 \mathrm{I}, \mathrm{p}<0.00 \mathrm{I}$ and $\mathrm{p}<0.00 \mathrm{I}$, respectively). Following $9.7 \pm 2.3$ injections, the mean VA gain at month 12 was +8.5 letters. Visual acuity after one year of treatment was correlated with baseline RV and baseline VA $(r=-0.542 p=0.003$ and $r=0.485$ $p=0.009$, respectively). The letters gain was correlated only with the baseline VA $(r=-0.528$, $p=0.004)$. A multiple regression analysis was performed to investigate the relationship between the baseline VA, RV, CRT, serous macular detachment, age, the number of the injections, and letter gain and final VA. The factors significantly affecting the letters gain and final VA were baseline VA and baseline RV $(p<0.00 \mathrm{I})$.

Conclusion: Baseline retinal volume seems to be an important factor predicting the response to anti-VEGF treatment in DME. Such objective and quantitative data would allow us to be more certain when discussing prognosis, treatment and monitoring strategies. Presumed prognostic factors as: macular ischemia, vitreoretinal interface abnormalities, cystoid degeneration and hard exudates should also be considered.

\section{INTRODUCTION}

Diabetic retinopathy (DR) is an entity of microangiopathy that arises from chronic hyperglycemia. Diabetic retinopathy has been shown to be associated with various vascular, inflammatory, and neuronal factors. ${ }^{[1]}$ Uncontrolled hyperglycemia, duration of diabetes, puberty, pregnancy, systemic hypertension, high serum lipid levels and obesity are among the important risk factors for the development of DR..$^{[1,2]}$ Diabetic macular edema (DME) causes visual loss with various complications, such as vitreous hemorrhage, retinal detachment, neovascular glaucoma. ${ }^{[3]}$ Diabetic macular edema is the most common cause of visual function loss in patients with diabetes. ${ }^{[4]}$ Approximately 14\% of patients develop DME, and the 10-year incidence of DME in patients with newly developed type II diabetes is calculated as $20 \%$.

Chronic hyperglycemia predisposes to the development of DME with the impacts of factors as free oxygen rad- icals, advanced glycation end products, protein kinase C. These factors may cause an increase in vascular endothelial growth factors (VEGFs) which contribute to the disruption of the blood-retina barrier. Recent studies have shown that VEGFs play an important role in the pathogenesis of DME. [1] Anti-VEGF agents have also been proven to be superior to focal / grid laser treatment in randomized controlled trials. $^{[10-13]} A$ humanized monoclonal antibody, bevacizumab (Avastin), has the ability to inhibit all VEGF isoforms and has been widely used in the treatment of DME. ${ }^{[13]}$

Optical coherence tomography (OCT) provides an in vivo sectional view from tissues thanks to its high resolution. OCT has recently become the standard method in the diagnosis and follow-up of different macular pathology. With spectral-domain OCT, the retina volume in circles with diameters of $1 \mathrm{~mm}, 3 \mathrm{~mm}$ and $6 \mathrm{~mm}$ can be automatically evaluated. In diabetic macular edema, the clinical picture covers a broad spectrum of morphological findings, and 
the response to anti-VEGF therapy varies on an individual basis. The relationship between the initial anatomical features and the functional gain obtained after anti-VEGF treatment was a matter of curiosity. It has been suggested that initial central retinal thickness (CRT) may be an important prognostic factor in determining the response to treatment. ${ }^{[14]}$

In this study, we aimed to investigate the relationship between baseline retinal volume (RV) and baseline CRT and visual acuity (VA) and letter gain (LG) at the end of one year in patients receiving bevacizumab treatment in the light of real-life data.

\section{MATERIALS AND METHODS}

Twenty-eyes of 19 patients who were injected intravitreal $0.05 \mathrm{~mL}$ (1.25 mg) bevacizumab (Avastin ${ }^{\circledR}$; Genentech, Inc., South San Francisco, CA) with the indication of DME between April 2013 and April 2017 were retrospectively analyzed. The study protocol was prepared in accordance with the Helsinki declaration and was approved by the ethics committee (date: 31.05.2019, no: 2019/002). Written informed consent was obtained from the participants before the treatment.

Age, gender, intraocular pressure, refractive error, corrected VA, the number of the injections and macular SDOCT scans were obtained from the medical records of the patients. Visual acuity measurements were performed under ambient conditions standardized with the ETDRS chart. VA values obtained with the ETDRS chart were converted to a logMAR unit for statistical analysis. Spectral Domain (SD) -OCT (Spectralis, Heidelberg Engineering, Heidelberg, Germany) was used for optical coherence tomography shots. The macula was scanned by taking 49 sections (5I2 A-scan) in $20^{\circ} \times 20^{\circ}$ area at $120 \mu \mathrm{m}$ intervals. The shooting was done by the same technician who had experience on the subject. With Spectralis software, $\mathrm{RV}$ in a 6 -mm diameter circle and SRK in I mm -diameter circle were determined automatically. The test results were evaluated by two experienced clinicians.

DME cases with baseline visual acuities between 20/40020/40 (20-70 letters) and central macular thickness $>300$ $\mu \mathrm{m}$ in SD-OCT were included in this study. At least six consecutive injections were applied at the beginning of the treatment until visual stabilization was achieved. When the activation findings, such as decreased visual acuity and/or increased retinal fluid, were observed during the follow- up period, re-treatment was applied. Intravitreal injections were applied in office conditions. Prophylactic topical antibiotic use after injection was not recommended.

Patients with epiretinal membrane, vitreoretinal traction, diffuse cystoid degeneration and subretinal fibrosis, proliferative diabetic retinopathy, cataracts, uveitis, glaucoma, degenerative myopia, ocular trauma, other retinal vascular, and optic nerve pathologies as determined based on optical coherence tomography examination, and patients with a history of ocular surgery (other than uncomplicated cataract surgery) is accompanied by, as well as ocular surgery (other than uncomplicated cataract surgery) were excluded from this study. Patients who underwent laser treatment and intravitreal corticosteroid injection before and after intravitreal bevacizumab treatment were also excluded.

SPSS version 15 was used for statistical analysis. The linear relationship between the two variables was evaluated by Pearson correlation analysis. Comparison of patient findings at baseline and one year after treatment was performed with paired t-test. The factors affecting the letter gain and final VA were evaluated by multivariate linear regression analysis. $\mathrm{P}<0.05$ was considered statistically significant.

\section{RESULTS}

Twenty-eight eyes of 19 patients were included in this study. The mean age of the patients participating in this study was $61.6 \pm 7.2(49-74)$ years. Seven patients $(37 \%)$ were female and 12 patients $(63 \%)$ were male. Twenty eyes were phakic ( $72 \%$ ) and eight ( $28 \%$ ) eyes were pseudophakic. Significant differences were detected between baseline VA [58.9 \pm I I 9 letters (35-75), CRT [564.2 \pm I 25. I $\mu \mathrm{m}(339-8 \mathrm{II})], \mathrm{RV}\left[\mathrm{I} 2.4 \pm 2.3 \mathrm{~mm}^{3}(8.9-\mathrm{I} 6.6)\right]$, and the final VA [67.4 \pm I I.6 letters (40-84)], CRT [4 I 0.2 \pm I $24.2 \mu \mathrm{m}$ (235-672)], RV [10.6 $\pm 2.2 \mathrm{~mm}^{3}$ (7.06-16.19)] $(p=0.00 \mathrm{I}$, $\mathrm{p}<0.00 \mathrm{I}$ and $\mathrm{p}<0.00 \mathrm{I}$, respectively) (Table I). The mean number of the injections was calculated as $9.7 \pm 2.3(6-13)$. At the end of one year, an average increase of +8.5 letters was obtained. When compared with baseline, $29 \%$ of eyes gained $\geq 15$ ETDRS letters.

Correlations were found between final VA, and baseline values of RV and VA $(r=-0.542 p=0.003, r=0.485 p=0.009$, respectively). Letter gain, however, was found to be correlated with only baseline VA $(r=-0.528, p=0.004)$. Multiple regression analysis evaluated the relationship between baseline VA, RV, CRT, presence of serous macular detach-

Table I. Comparison between baseline, and postoperative first-year values

\begin{tabular}{lcrr}
\hline Parameter & Baseline & I2. month & p \\
\hline $\mathrm{VA} \pm \mathrm{SD}$, letter gain (range) & $58.9 \pm 11.9(35-75)$ & $67.4 \pm 11.6(40-84)$ & $=0.001$ \\
$\mathrm{CRT} \pm \mathrm{SD}, \mu \mathrm{m}$ (range) & $564.2 \pm 125.1(339-8 \mathrm{II})$ & $410.2 \pm 124.2(235-672)$ & $<0.001$ \\
$\mathrm{RV} \pm \mathrm{SD}, \mathrm{mm}^{3}$ (range) & $12.4 \pm 2.3(8.9-16.6)$ & $10.6 \pm 2.2(7.06-16.19)$ & $<0.001$ \\
\hline
\end{tabular}

VA: Visual acuity; RV: Retina volume; CRT: Central retina thickness; SD: Standard deviation; p: Statistical significance. 
Table 2. Correlations between baseline visual acuity, and retina volume, final visual acuity, and letter gain as determined based on multple regression analysis

\begin{tabular}{lccccccc}
\hline & \multicolumn{4}{c}{ Final visual acuity } & & \multicolumn{2}{c}{ Letter gain } \\
\cline { 2 - 4 } \cline { 7 - 8 } & $\mathbf{B}$ & $\mathbf{p}$ & $\mathbf{9 5 \%}$ confidence interval & & B & P & 95\% confidence interval \\
\hline Baseline VA & 0.351 & 0.040 & $0.016 / 0.666$ & & -0.658 & $<0.001$ & $-0.984 /-0.334$ \\
Baseline RV & -0.434 & 0.013 & $-3.869 /-0.503$ & & -0.421 & 0.013 & $-3.869 /-0.503$ \\
\hline
\end{tabular}

VA: Visual acuity; RV: Retina volume; B: Standardized beta; p: Statistical significance.

ment, age and number of the injections, letter gain, and final VA. Factors affecting letter gain and final VA were found as baseline VA and RV (Table 2). While a positive relationship was observed between the final VA, baseline $V A$, a negative relationship was determined between the final VA and the baseline RV. In addition, there was a significant negative correlation was observed between letter gain and baseline VA and baseline RV (Table 2).

\section{DISCUSSION}

Today, anti-VEGF agents are widely used in the treatment of DME and have been shown in randomized controlled trials to reduce the loss of visual function. ${ }^{[8,9,15-18]}$ Although effective results have been obtained with the administration of anti-VEGF in these cases, visual gains differ among patients. Determining the factors affecting the treatment response in advance provides benefits to the clinician's determination of prognosis and treatment planning process and increases the patient's compliance with the treatment.

Good and bad prognostic factors were investigated in post-hoc analysis of randomized controlled trials. ${ }^{[8,9,15-18]}$ Increased baseline VA was found as good, decreased baseline VA, foveal atrophy and foveal pigmentation as poor prognostic factors in the post-hoc analysis of the READ (Ranibizumab for Edema of the Macula in Diabetes) study. In the post-hoc analysis of RIDE/RISE (A Study of Ranibizumab Injection in Subjects with Clinically Significant Macular Edema with Center Involvement Secondary to Diabetes Mellitus), also increased baseline VA was detected as good and decreased baseline VA and history of panretinal photocoagulation as poor prognostic factors.

In the RESTORE (Ranibizumab Monotherapy or Combined with Laser versus Laser Monotherapy for Diabetic Macular Edema) study, it was observed that there were more letter gains in patients with short-term diabetes and DME history, and lower VA values. ${ }^{[17]}$ In the DRCR.net Protocol I study, younger age, mild diabetic retinopathy at baseline, duration of diabetes less than 15 years, absence of epiretinal membranes, a significant decrease in CRT in the first year of treatment, and decreased baseline VA were associated with increased letter gain. ${ }^{[18]}$

In our study, a positive correlation was found between the final and baseline VA values in line with previous studies. $[15,16]$ At the same time, the letter gain was inversely correlated with the baseline VA as in other studies. ${ }^{[17,18]}$
This finding can be explained by the ceiling effect phenomenon. In addition to previous studies, a negative correlation was found between the baseline RV and the final VA. In addition, in the multiple regression analysis, the factors affecting the final VA and letter gain were determined as baseline VA and RV. The increased baseline RV in the central area of $6 \mathrm{~mm}$ in diameter shows that the disease is very severe, and widespread and suggests that it may be a more important prognostic factor in terms of visual prognosis compared to CRT.

The main limitations of our study include its single-centered and retrospective design performed with a limited number of cases and a short follow-up period. On the other hand, because we provided real-life data, this adds value to our study.

Interestingly, the average the number of the injections we applied in the Ist year is higher than the number of the injections (average seven injections) applied in clinical studies, such as BOLT and RESTORE.

As a result, it was found that decreased RV in DME cases caused better visual results after the anti-VEGF treatment. With the use of optical coherence tomography, objective and quantitative evaluation of the structural changes of the macula can be provided in such patients and visual prognosis can be guiding concerning planning the treatment and follow-up strategy. Our results should be supported by a larger patient series with longer follow-up. In the evaluation of these cases, potential prognostic factors, such as macular ischemia, vitreoretinal interface pathologies, cystoid degeneration and presence of hard exudate, that may affect the treatment response should be taken into consideration.

Ethics Committee Approval

Approved by the local ethics committee (date: 31.05 .2019 , no: 2019/002).

Informed Consent

Retrospective study.

Peer-review

Internally peer-reviewed.

Authorship Contributions

Concept: M.H., M.G.E., M.K.; Design: M.H., M.G.E., M.K.; Supervision: M.H., M.G.E., M.K.; Fundings: M.H., M.G.E.; Materials: M.H., M.G.E.; Data: M.H., M.G.E.; Analysis: M.H., M.G.E.; Literature search: M.H., M.G.E.; Writing: 
M.H., M.G.E.; Critical revision: M.G.E., M.K.

Conflict of Interest

None declared.

\section{REFERENCES}

1. Wang W, Lo ACY. Diabetic Retinopathy: Pathophysiology and Treatments. Int J Mol Sci 2018;19:E1816. [CrossRef]

2. Liu Y, Yang J, Tao L, Lv H, Jiang X, Zhang M, et al. Risk factors of diabetic retinopathy and sight-threatening diabetic retinopathy: a cross-sectional study of 13473 patients with type 2 diabetes mellitus in mainland China. BMJ Open 2017;7:e016280. [CrossRef]

3. Nentwich MM, Ulbig MW. Diabetic retinopathy - ocular complications of diabetes mellitus. World J Diabetes 2015;6:489-99. [CrossRef]

4. Moss SE, Klein R, Klein BE. The 14-year incidence of visual loss in a diabetic population. Ophthalmology 1998;105:998-1003. [CrossRef]

5. Diabetes Control and Complications Trial Research Group, Nathan DM, Genuth S, Lachin J, Cleary P, Crofford O, et al. The effect of intensive treatment of diabetes on the development and progression of long-term complications in insulin-dependent diabetes mellitus. $\mathrm{N}$ Engl J Med 1993;329:977-86. [CrossRef]

6. Early Treatment Diabetic Retinopathy Study Research Group. Photocoagulation for diabetic macular edema. Early Treatment Diabetic Retinopathy Study report number 1. Arch Ophthalmol 1985;103:1796-806. [CrossRef]

7. Antonetti DA, Barber AJ, Hollinger LA, Wolpert EB, Gardner TW. Vascular endothelial growth factor induces rapid phosphorylation of tight junction proteins occludin and zonula occluden 1. A potential mechanism for vascular permeability in diabetic retinopaty and tumors. J Biol Chem 1999;274:23463-7. [CrossRef]

8. Michaelides M, Kaines A, Hamilton RD, Fraser-Bell S, Rajendram $\mathrm{R}$, Quhill $\mathrm{F}$, et al. A prospective randomized trial of intravitreal bevacizumab or laser therapy in the management of diabetic macular edema (BOLT study) 12-month data: report 2. Ophthalmology 2010;117:1078-86. [CrossRef]

9. Do DV, Schmidt-Erfurth U, Gonzalez VH, Gordon CM, Tolentino M, Berliner AJ, et al. The DA VINCI Study: phase 2 primary results of VEGF Trap-Eye in patients with diabetic macular edema. Ophthalmology 2011;118:1819-26. [CrossRef]

10. Göker YŞ, Tekin K, Kızıltoprak H, Üçgül Atılgan C, Kosekahya P. Bevacizumab Therapy For Diabetic Macular Edema: A Real Life Study. Dicle Med J 2019;46:235-40.

11. Oruç Dündar S, Çakmak H. Place of ANTI-VEGF in Diabetic Macular Edema. Ret-Vit Özel Sayı 2015;23:43-9.

12. Batığlu F. Ranibizumab Monotherapy in Diabetic Macular Edema. Turkiye Klinikleri J Ophthalmol-Special Topics 2013;6:61-6.

13. Bardak Y. Bevacizumab Monotheraphy in Diabetic Macular Edema. Turkiye Klinikleri J Ophthalmol-Special Topics 2013;6:67-70.

14. Soheilian M, Ramezani A, Yaseri M, Mirdehghan SA, Obudi A, Bijanzadeh $B$. Initial macular thickness and response to treatment in diabetic macular edema. Retina 2011;31:1564-73. [CrossRef]

15. Channa R, Sophie R, Khwaja AA, Do DV, Hafiz G, Nguyen QD, et al. Factors affecting visual outcomes in patients with diabetic macular edema treated with ranibizumab. Eye (Lond) 2014;28:269-78.

16. Sophie R, Lu N, Campochiaro PA. Predictors of functional and anatomic outcomes in patients with diabetic macular edema treated with ranibizumab. Ophthalmology 2015;122:1395-401. [CrossRef]

17. Mitchell P, Chong V. Baseline predictors of 3-year responses to ranibizumab and laser photocoagulation therapy in patients with visual impairment due to diabetic macular edema (DME): the RESTORE study. Invest Ophthalmol Vis Sci 2013;54:2373-3.

18. Bressler SB, Qin H, Beck RW, Chalam KV, Kim JE, Melia M, et al. Factors associated with changes in visual acuity and central subfield thickness at 1 year after treatment for diabetic macular edema with ranibizumab. Arch Ophthalmol 2012;130:1153-61. [CrossRef]

\section{Diyabetik Maküla Ödemi Tedavisinde Başlangıç Retina Hacminin Görsel Sonuç Üzerindeki Etkisi}

Amaç: Diyabetik maküla ödemi (DMÖ) nedeniyle intravitreal bevacizumab tedavisi uygulanan hastalarda başlangıç retina hacminin son görme keskinliği (GK) ve harf kazanımı (HK) ile ilişkisini araştırmak.

Gereç ve Yöntem: Klinik olarak anlamlı DMÖ nedeniyle intravitreal bevacizumab enjeksiyonu yapılan 19 hastanın 28 gözü geriye dönük olarak incelendi. Spektral-domain optik koherens tomografi (SD-OKT) ile ölçülen başlangıç retina hacmi (RH) ve santral retinal kalınlığının (SRK) bir yıl sonundaki GK ve harf kazanımı ile ilişkisi incelendi.

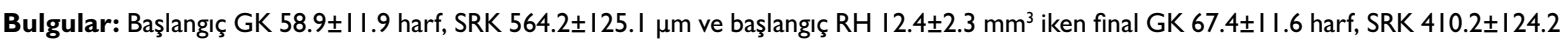
$\mu \mathrm{m}$ ve final $\mathrm{RH} 10.6 \pm 2.2 \mathrm{~mm}^{3}$ idi (sırasıyala, $\mathrm{p}=0.00 \mathrm{I}, \mathrm{p}<0.00 \mathrm{I}, \mathrm{p}<0.00 \mathrm{I}$ ). Ortalama $9.7 \pm 2.3$ enjeksiyon sonrasında birinci yılda ortalama +8.5 harf kazanımı sağlandı. Final GK ile başlangıç RH ve başlangıç GK korale bulundu (sırasıyla; $r=-0.542 p=0.003$ ve $r=0.485 p=0.009$ ). Harf kazanımı ise sadece başlangıç GK ile korale bulundu $(r=-0.528, p=0.004)$. Çoklu regresyon analizi sonrasında harf kazanımı ve final $G K ' y e$ etki eden faktörlerin başlangıç $G K$ ve başlangıç $R H$ olduğunu bulundu $(p<0.00 I)$.

Sonuç: Diyabetik maküla ödeminde başlangıç RH'nin intravitreal anti-VEGF tedavisi yanıtının belirlenmesinde SRK'dan daha anlamlı bir faktör olduğunu görülmüştür. Objektif ve kantitatif bilgi sağlayan bu gibi veriler görsel prognoz tayini, tedavi ve takip stratejisinin planlanması açısından yol gösterici olabilir. Tedavi yanıtını etkileyebilen, olası prognostik faktörler: maküla iskemisi ve vitreoretinal arayüz patolojileri, kistoid dejenerasyon, sert eksuda varlığı gibi morfolojik özellikler de göz önünde bulundurulmalıdır.

Anahtar Sözcükler: Bevacizumab; diyabetik maküla ödemi; diyabetik retinopati; maküla kalınlığ; optik koherens tomografi; retina hacmi. 